\title{
A drift study of larval fish survival*
}

\author{
Louis Fortier ${ }^{1} \&$ William C. Leggett ${ }^{2}$ \\ 1 Centre Champlain des Sciences de la Mer, Ministère des Pêches et des Océans, 901 Cap Diamant, Québec G1K 7Y7, Canada \\ 2 Department of Biology, McGill University, 1205 Ave Dr Penfield, Montreal H3A 1B1, Canada
}

\begin{abstract}
The early survival of capelin (Mallotus villosus) was studied by tracking a cohort of larvae and monitoring the decline in their abundance during the transition from yolk-sac nutrition to exogenous feeding. A free-drifting drogue equipped with temperature and salinity probes was launched in the surface layer of the lower St. Lawrence estuary. Larval capelin abundance around the drogue was measured at $2 \mathrm{~h}$ intervals for $5.6 \mathrm{~d}$. The T-S (temperature-salinity) diagram for the duration of the experiment revealed that the drifter crossed 7 distinct water masses. Capelin larvae transported by each of the different water masses were considered as distinct subpopulations. One water mass was monitored for a period of $46 \mathrm{~h}$ beginning on the second day following the final resorption of the vitelline reserves in $50 \%$ of the subpopulation. Over these $46 \mathrm{~h}$, capelin abundance decreased from 34 larvae $\mathrm{m}^{-3}$ to 5 larvae $\mathrm{m}^{-3}$. Progressive mixing of the surface layer with deep water containing no larvae explained $5.6 \%$ of the reduction in larval density. The decline in capelin number was adequately described by an exponential-decay model with mortality constant over time. The estimated hourly mortality rate was $0.0339 \mathrm{~h}^{-1}\left(\mathrm{SD}=0.0061 \mathrm{~h}^{-1}\right)$ corresponding to a daily survival rate of $43.7 \%$ $\mathrm{d}^{-1}$. A logistic model, reflecting the sigmoid survival curve proposed by Hjort $(1914,1926)$, also fitted the observations, and predicted more realistic values of capelin density at emergence than the constant exponential decay model. Partial results from the other water masses confirmed that capelin mortality was high at the resorption of the yolk sac. The isolation of capelin larvae into subpopulations transported by independent ecological units (the distinct water masses) suggested that meso-scale $(1$ to $10 \mathrm{~km})$ spatial variations in survival could be important.
\end{abstract}

\section{INTRODUCTION}

The majority of estuarine and marine fish produce planktonic larvae. It is generally believed that recruitment to the adult population depends in part on the survival of these planktonic larvae (see Leiby 1984, for a recent review of the paradigm). Several hypotheses and simulation models have been developed to explain and describe the early survival of fish (e.g. Hjort 1914, 1926, Cushing 1972, Jones 1973, Lasker 1975, 1981, Vlymen 1977, Beyer \& Laurence 1979). The verification of these hypotheses and models has been and is still hindered by the difficulty of monitoring changes in the abundance and distribution of the planktonic stages. Traditionally, data used in the derivation of early survival curves of fish came from large-scale surveys of ichthyoplankton (see Dahlberg 1979 for a review). The heuristic value of these curves has been questioned (Marr 1956, Gulland 1965, May 1974, Dahl-

\footnotetext{
- Contribution to the program of GIROQ (Groupe interuniversitaire de recherches océanographiques du Québec)
}

berg 1979). Three major criticisms were formulated. First, the time resolution achievable when a large geographical area is covered may be insufficient to detect contracted periods of high mortality related to specific developmental bridges. Second, since the production of eggs spans several weeks or months in most species, the larval population usually comprises more than 1 cohort. The averaging of age-abundance data for several distinct cohorts will yield an artificially smoothed survival curve that may bear little resemblance to the actual survival curve of a synchronously developing cohort. Third, this averaging process also results in the loss of information on meso-scale (1 to $10 \mathrm{~km}$, hours to days) spatial or temporal variations in survival. It is then impossible to investigate the causes of mortality by linking such variations in survival to environmental correlates.

To achieve a finer resolution in time and to preserve meso-scale variations in survival, several authors have proposed monitoring the decline in the abundance of distinct cohorts of larvae transported by discrete water masses (e.g. Lasker 1975, Hunter 1976, Shepherd \& 
Cushing 1980, Saville \& Schnack 1981). In the present study, we applied this approach to the investigation of capelin Mallotus villosus survival during the early planktonic drift in the lower estuary of the St. Lawrence.

The adhesive eggs of capelin are buried in sandy beaches and intertidal flats on both shores of the St. Lawrence upper estuary (Parent \& Brunel 1976). The eggs hatch in the coarse sand and the larvae emerge in the brackish surface layer of the estuary. The emergence of the larvae from the spawning beds is sporadic, swarms of larvae being released under specific conditions of turbulence and/or temperature (Frank \& Leggett 1981, Fortier \& Leggett unpubl.). The cohorts injected in the brackish layer of the upper estuary are rapidly transported by near-surface circulation to the lower estuary (Jacquaz et al. 1977, Fortier \& Leggett 1982, 1983, de Lafontaine et al. 1981, 1984).

A possible solution to the difficult problem of tracking a distinct cohort at sea is to flag an aggregation of the planktonic larvae with a free-drifting drogue (Miller et al. 1963, Dragesund \& Nakken 1971, Hempel \& Schnack 1971, Bjorke 1978, Smith et al. 1978, Conte et al. 1979, Shelton \& Hutchings 1982, Henri et al. 1985). In such an aggregation, dispersion as well as mortality will contribute to the reduction of the initial density of the larvae (Talbot 1977, 1978, Smith 1978). Failure to consider the effect of dispersion may lead to overestimations of the actual mortality rate. In the St. Lawrence estuary, the horizontal dispersal of early developmental stages of capelin parallels the dispersal of the freshwater fraction of the estuary (Fortier \& Leggett $1982,1983)$. We proposed that the decline of the freshwater fraction in a given volume of water (or the increase of its complement salinity), would be a measure of the contribution of dispersion to the reduction of larval concentration (Fortier \& Leggett 1982). Corrected estimates of mortality could then be obtained by subtracting this contribution from the decline in larval capelin density recorded around a free-drifting drogue.

Hjort $(1914,1926)$ suggested that the transition from yolk sac nutrition to exogenous feeding may be critical for the success of the annual recolonization of the environment by the planktonic stages of fish. This hypothesis has yet to be thoroughly tested in nature (Marr 1956, May 1974, Solemdal \& Ellersten 1984), and its evaluation remains relevant to the understanding of year-class strength variability. A prediction derived from Hjort's hypothesis is that mortality in early developmental stages of fish should increase at the transition from larval to postlarval life and decrease thereafter. We report here the results of an attempt at verifying this prediction by tracking a distinct cohort of capelin larvae and monitoring the decline in their density during the early planktonic drift in the lower estuary of the St. Lawrence. Following the nomenclature of Russel (1976 p. 4), we consider postlarval life to begin at the resorption of the vitelline reserves.

\section{METHODS}

Area studied. The St. Lawrence lower estuary is partially mixed in summer (El-Sabh 1979). El-Sabh (1979) proposed a general pattern of surface circulation characterized along the north shore by a cyclonic eddy between the confluence of the Saguenay Fjord and Forestville, and a larger anticyclonic gyre from Forestville to Pointes des Monts (Fig. 1a). Along the south shore, surface circulation is seaward and relatively fast (Fig. 1a). These large-scale features of the near-surface

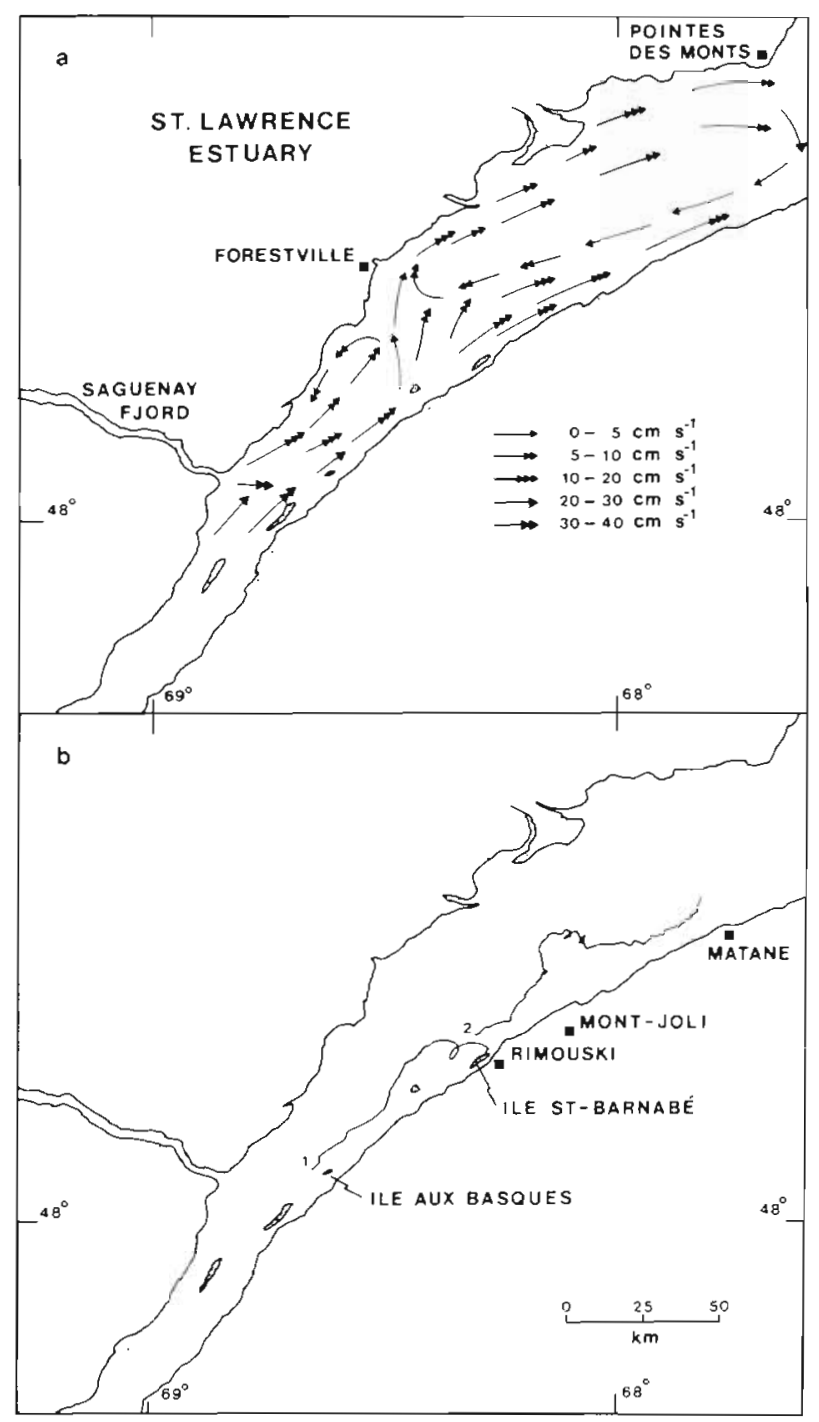

Fig. 1. St. Lawrence lower estuary. (a) The general pattern of circulation proposed by El-Sabh (1979). (b) The trajectory of the drifter after the first (1) and second (2) launch 
circulation are subject to low-frequency fluctuations in intensity and position (El-Sabh et al. 1982).

Sampling. On 11 June 1981, a Challenger-type drogue was released in the surface waters of the lower estuary. The 4 branches of the cruciform sail consisted of $1.9 \mathrm{~m}$ wide by $1.2 \mathrm{~m}$ high panels supported by a $0.3 \mathrm{~m}$ radius spherical surface buoy. The center of the sail was located at a depth of $6 \mathrm{~m}$. Two Aanderaa recording current meters equipped with conductivity and temperature sensors were positioned $2 \mathrm{~m}$ above and below the center of the sail, at depths of 4 and $8 \mathrm{~m}$ respectively. The recording interval was set to $1 \mathrm{~min}$. A radar reflector, a radio source, and a light source, supported by a low-drag secondary buoy, were used to track the drogue. Wind speed and direction were recorded at Mont-Joli (Fig. 1b).

At $2 \mathrm{~h}$ intervals, a $50 \mathrm{~cm}$ opening-and-closing bongo system equipped with flowmeters, a time-depth recorder, and fitted with $150 \mu \mathrm{m}$ mesh nets was used to sample the surface to $15 \mathrm{~m}$ depth interval and the $15 \mathrm{~m}$ to $50 \mathrm{~m}$ interval (or bottom depending on depth). The sampler was towed in a multiple oblique trajectory at a speed of $6.0 \mathrm{~km} \mathrm{~h}{ }^{-1}(3.2 \mathrm{kn})$ within $0.5 \mathrm{~km}$ of the drogue. The depth of the sampler was monitored with a Furuno system. The average volume of water filtered by each net was $213 \mathrm{~m}^{3}\left(\mathrm{SD}=53 \mathrm{~m}^{3}, \mathrm{n}=272\right)$. Samples were preserved in a $4 \%$ solution of buffered formalin. Fish larvae and large zooplankters were completely sorted. From each sample, a maximum of
50 capelin larvae were randomly taken and measured to the nearest $0.04 \mathrm{~mm}$ using a photographic technique. The estimates of abundance presented are the average of the 2 nets of the sampler. In regression analysis, abundance values were weighted by the coefficient of variance $(\mathrm{SD} / \overline{\mathrm{X}})$ of the 2 duplicates obtained in 1 bongo tow.

\section{RESULTS}

\section{Trajectory and behaviour of the drifter}

After a rapid survey of larval capelin abundance in the area of the Saguenay confluence, the drifter was released in a zone of high larval density ( $>50$ larvae $\mathrm{m}^{-3}$ ), off Ile aux Basques (Fig. 1b). As expected, the general direction of drift was seaward (Fig. 1b). For the first $30 \mathrm{~h}$, tidal flood produced a deceleration of drift but no reversal of direction. During this period, drift speed averaged $3.0 \mathrm{~km} \mathrm{~h}^{-1}$, reaching peaks of $6.5 \mathrm{~km}$ $\mathrm{h}^{-1}$. A first tidal loop occurred off Rimouski (Fig. 1b). At this point, drift speed decreased, the drogue moved towards shore and stranded on Ile St-Barnabé at high tide, $36 \mathrm{~h}$ after the first launch (Fig. 1b). The drogue was retrieved and re-launched $12 \mathrm{~h}$ later, on the next high tide, $8 \mathrm{~km}$ off Ile St-Barnabé (Fig. 1b). After the second launch, drift speed averaged $1.6 \mathrm{~km} \mathrm{~h}^{-1}$ and seldom exceeded $2.5 \mathrm{~km} \mathrm{~h}^{-1}$. The drogue moved seaward again, roughly following the main axis of the

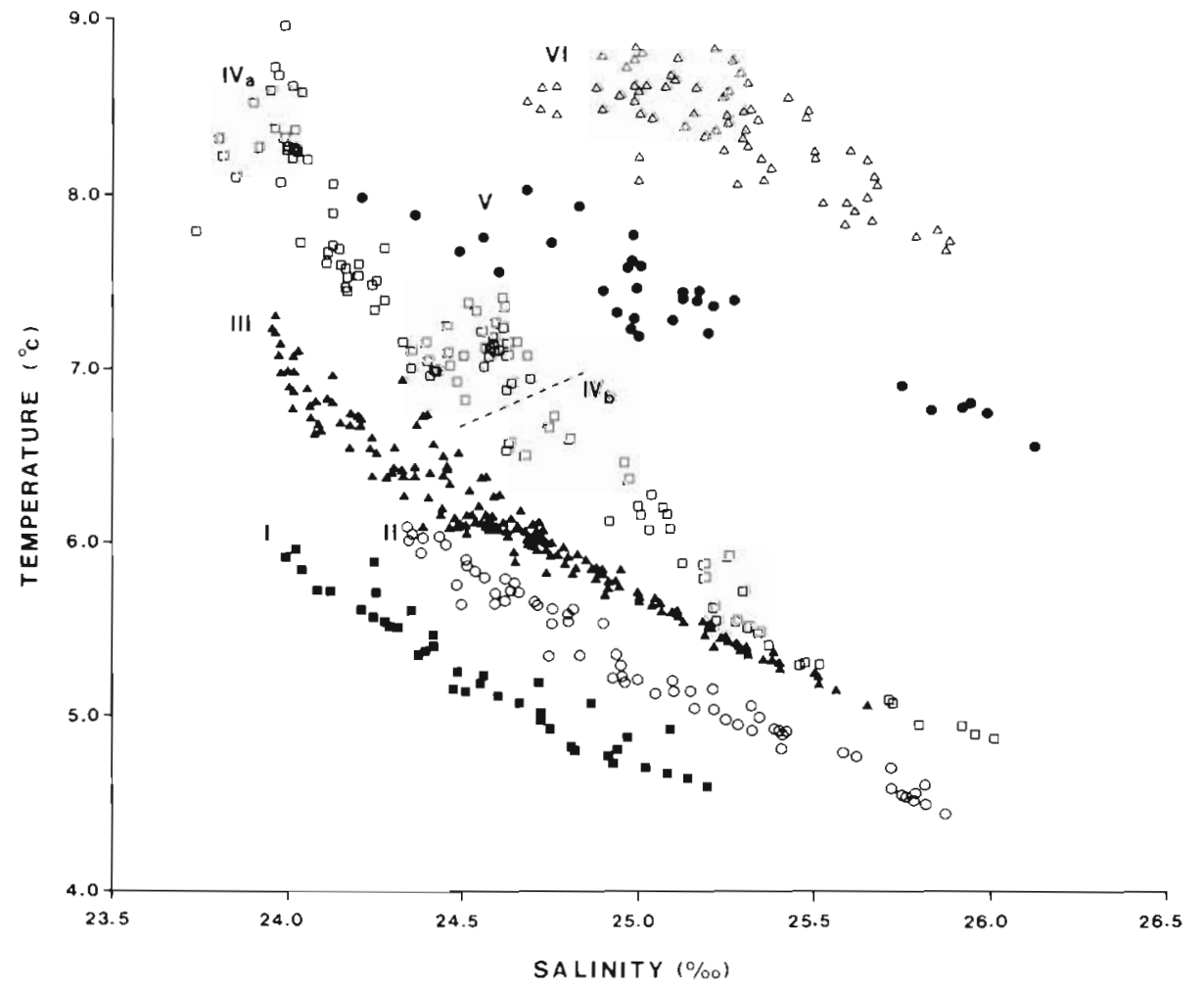

Fig. 2. Temperature-salinity diagram. T-S pairs recorded every $30 \mathrm{~min}$ at depths of 4 and $8 \mathrm{~m}$ were plotted. Distinct water masses crossed by the drifter are identified in Roman numerals 
estuary except for a semicircular meander north of Mont-Joli (Fig. 1b). The drogue was retrieved off Matane, $86 \mathrm{~h}$ after the second launch. The net distance travelled from the first immersion to the final retrieval was about $150 \mathrm{~km}$ in a NE direction, at an average net velocity of $1.2 \mathrm{~km} \mathrm{~h}^{-1}$.

A first question is whether the trajectory of the drogue was representative of the trajectory followed by the initial volume of water into which it was launched. Current speed and direction recorded by the instruments positioned above and below the sail represented the displacement of the drifter relative to the surrounding waters. Under the assumption that the drifter remained in the same volume of water, we would expect the velocity vector to be null or to cancel out when integrated over a tidal cycle or more. However, the integration of the velocity vector over the entire period of drift (excluding the $12 \mathrm{~h}$ following stranding when the drogue was taken back on board), indicated a $22.8 \mathrm{~km}$ net displacement of the drifter relative to the initial volume of water. The speed of the drifter relative to the surrounding waters, was weakly but significantly correlated to wind speed $13 \mathrm{~h}$ earlier at Mont-Joli (cross-correlation, $\mathrm{r}_{\max }=0.441, \mathrm{n}=72$, $\mathrm{P}<0.01$, lag $=13 \mathrm{~h}$ ). Thus, wind stress at the surface was in part responsible for the displacement of the drifter relative to the surrounding waters.

Table 1. The section of the time series during which each of the 7 different water masses was occupied by the drifter. $\mathrm{N}$ is the number of ichthyoplankton samples taken in each water mass

\begin{tabular}{|lrr|}
\hline Water mass & Time interval (h) & N \\
\hline I & $0.0-9.5$ & 5 \\
II & $10.0-23.0$ & 7 \\
IVa & $23.5-35.0$ & 6 \\
III & $47.5-93.5$ & 24 \\
IVb & $94.0-109.5$ & 8 \\
V & $110.0-118.0$ & 5 \\
VI & $118.5-134.0$ & 8 \\
\end{tabular}

Table 2. Compared abundance of some meroplanktonic taxa in Water Masses IVa and IVb

\begin{tabular}{|c|c|c|c|}
\hline \multirow[t]{2}{*}{ Taxon } & \multirow[t]{2}{*}{ Stage } & \multicolumn{2}{|c|}{ Average density $\mathrm{m}^{-3}$} \\
\hline & & $\begin{array}{c}\text { Water } \\
\text { Mass } \\
\text { IVa }\end{array}$ & $\begin{array}{l}\text { Water } \\
\text { Mass } \\
\text { IVb }\end{array}$ \\
\hline $\begin{array}{l}\text { Clupea harengus } \\
\text { harengus }\end{array}$ & Larva & 1.5 & Absent \\
\hline Balanus sp. & Larva & Absent & 3.9 \\
\hline Gadus morhua & Egg & 40.1 & 1.9 \\
\hline Decapoda & Larva & Absent & 21.1 \\
\hline
\end{tabular}

Given the small-scale $(<5 \mathrm{~km})$ horizontal variability in near-surface salinity and temperature reported for the area (Levasseur et al. 1983, Lavoie et al. 1984), this displacement of $22.8 \mathrm{~km}$ away from the initial volume of water could have taken the drifter across several distinct water masses. To determine whether or not the drogue wandered across water masses of different nature, the temperatures recorded at 4 and $8 \mathrm{~m}$ of depth were plotted against corresponding salinities. On a temperature versus salinity (T-S) diagram, an estuarine water mass formed by the incomplete mixing of warm and fresh fluvial water with cold and saline oceanic water will appear as a straight line of negative slope. The T-S diagram revealed 6 distinct T-S lines corresponding to at least 6 different water masses (Fig. 2). These different water masses were crossed in succession, the drifter occupying Water Mass I for the first $9.5 \mathrm{~h}$ of the experiment, Water Mass II for the following $13.0 \mathrm{~h}$, etc. (Table 1). In 1 instance the drogue drifted back into a previously encountered water type: the T-S signature of Water Mass IVa sampled from $\mathrm{t}=23.5$ to $\mathrm{t}=35.0 \mathrm{~h}$ (immediately before the stranding of the drogue) was identical to the T-S signature of Water Mass IVb crossed from $t=94.0$ to $\mathrm{t}=109.5 \mathrm{~h}$ (Table 1 ). The similarity of the T-S signatures suggested that the same water mass was sampled during these 2 periods. However, sharp differences in the composition of meroplankton for the 2 periods demonstrated that the drifter actually returned in a different water mass (Table 2).

Salinity and temperature couples recorded at either 4 or $8 \mathrm{~m}$ fell on the same T-S line, indicating a continuity of the water masses in the vertical plane. The transition from 1 water mass to the next was sharp, few $\mathrm{T}$-S points belonging to more than 1 distinct cloud of T-S points (Fig. 2).

\section{Larval capelin}

The majority $(87.9 \%)$ of capelin larvae were captured in the 0 to $15 \mathrm{~m}$ depth stratum. Capelin length was normally distributed around an average of $5.51 \mathrm{~mm}$ (Fig. 3). No significant correlation was found between larval capelin length and time (Fig. 4a). Over the $5.6 \mathrm{~d}$ of sampling, the percentage of larvae with visible yolk sac decreased linearly from an average of $35 \%$ to $0 \%$ (Fig. 4 b). Thus, our sampling covered that section of the downstream drift of the larvae corresponding to the final resorption of the yolk reserves, and during which no significant growth took place

Capelin larvae sampled in the different water masses were submitted to different environmental conditions during drift, as exemplified by the distinct temperature regimes prevailing in each water mass (Fig. 


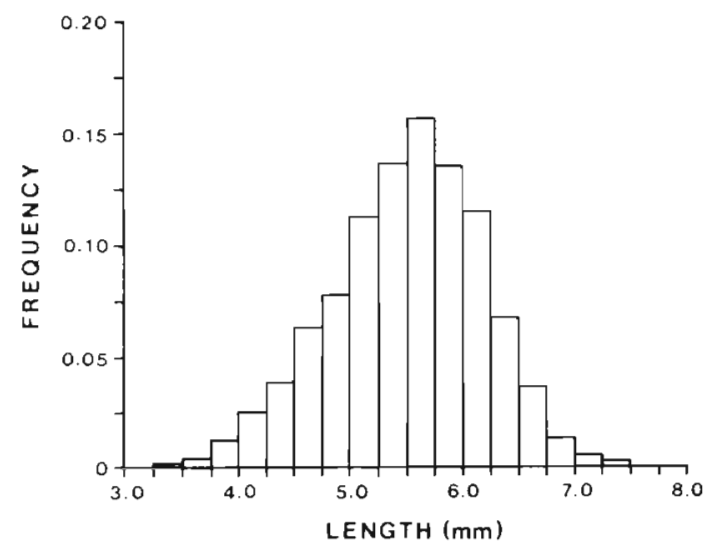

Fig. 3. Mallotus villosus. Length frequency distribution of capelin larvae $(\overline{\mathrm{X}}=5.51 \mathrm{~mm}, \mathrm{SD}=0.67 \mathrm{~mm}, \mathrm{n}=3437)$
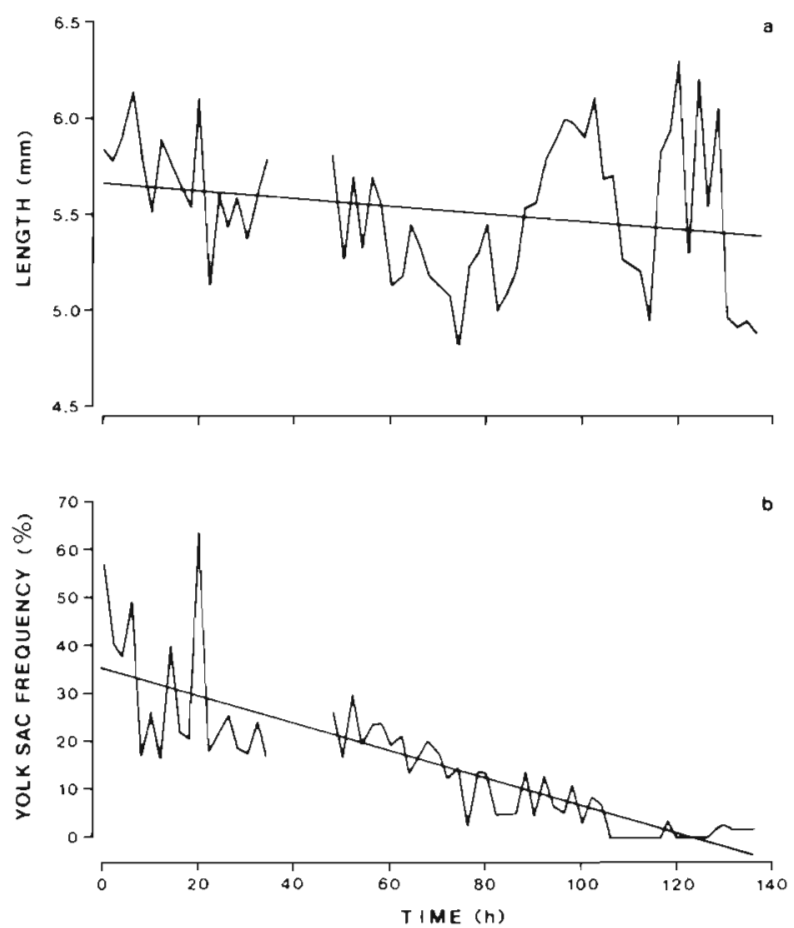

Fig. 4. Mallotus villosus. Time series of average length (a) and yolk sac frequency (b) of capelin larvae sampled around the drifter in the surface to $15 \mathrm{~m}$ depth stratum. Regression models are: length $=5.665-0.002$ time $\left(r^{2}=0.05, n=63\right.$, $\mathrm{P}=0.09$ ) and yolk sac frequency $=35.1-0.287$ time $\left(\mathrm{r}^{2}=0.692, \mathrm{n}=63, \mathrm{P}<0.001\right)$

2). Accordingly, larvae from the distinct water masses were treated as distinct subpopulations (sensu Roff 1974) in the investigation of mortality. Six of the 7 water masses were occupied by the drifter for periods of less than $16 \mathrm{~h}$ (Table 1). Results from these water masses gave a partial picture only of the decline in capelin number. Water Mass III was monitored without interruption for $46 \mathrm{~h}$, and the remainder of this section will concentrate on the more complete picture of the decline in larval capelin abundance obtained from this water mass

\section{Larval capelin survival in Water Mass III}

In Water Mass III, yolk sac frequency decreased linearly with time (Fig. 5). The slope of the regression $\left(-0.427 \% \mathrm{~h}^{-1}\right)$ corresponded to a daily rate of decrease in yolk sac frequency of $10.25 \% \mathrm{~d}^{-1}$. As expected, salinity tended to increase over the $46 \mathrm{~h}$ of seaward drift. Variations in salinity consisted of a linear trend onto which short-term cyclical fluctuations of a roughly semidiurnal period were superimposed (Fig. 6a). The decline in capelin abundance over this period appeared curvilinear (Fig. 6b) and could be adequately described by the standard equation for exponential decay

$$
N_{t}=N_{o} e^{-z t}
$$

where $N_{t}=$ capelin number at time $t_{i} N_{0}=$ initial number; $Z$ = exponential rate of decay. Positive anomalies in larval capelin abundance (i.e. values higher than predicted by the trend) generally corresponded to negative anomalies in salinity and vice versa (Fig. 6b). The residuals of the regression of larval abundance against time were significantly correlated to the residuals of the regression of salinity against time $(\mathrm{r}=-0.444, \mathrm{n}=24, \mathrm{P}<0.03)$, indicating that the inverse correspondence between abundance anomalies and salinity anomalies was statistically significant.

These semidiurnal inverse covariations in capelin density and salinity may have been caused by internal tides which are a common phenomenon in the area (Forrester 1974). The propagation of an internal tide will bring a semidiurnal shoaling of the pycnocline as schematized in Fig. 7. Capelin larvae are concentrated within the mixed layer above this pycnocline (Fortier \&

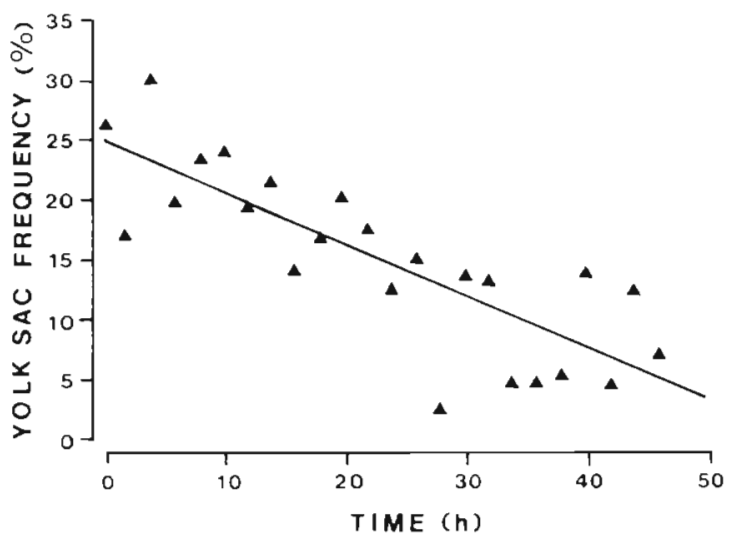

Fig. 5. Mallotus villosus. Time series of capelin yolk sac frequency in Water Mass III. Regression model is: yolk sac frequency $=24.7-0.427$ time $\left(\mathrm{r}^{2}=0.663, \mathrm{n}=24, \mathrm{P}<0.001\right)$ 

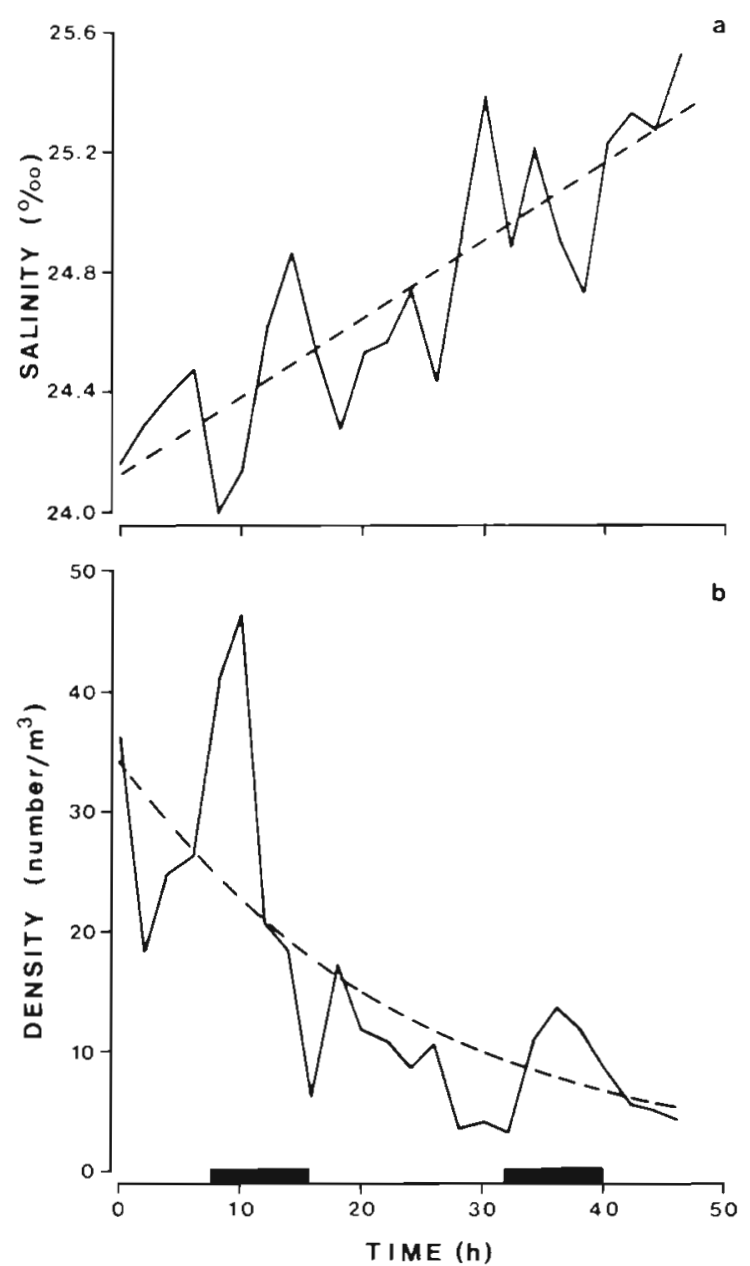

Fig. 6. Time series of salinity (a) and larval capelin density (b) in Water Mass III. Regression models are: salinity $=24.13+$ 0.026 time $\left(\mathrm{r}^{2}=0.727, \mathrm{n}=24, \mathrm{P}<0.001\right)$, and larval capelin density $=34.02 \mathrm{e}^{-0.0339 \mathrm{nme}}\left(\mathrm{r}^{2}=0.548, \mathrm{n}=24, \mathrm{P}<0.001\right)$. For the regression analysis, values of capelin abundance were weighted by the coefficient of variance (SD/X) of the 2 duplicates from the bongo sampler. Heavy horizontal bars on the abscissa correspond to nighttime

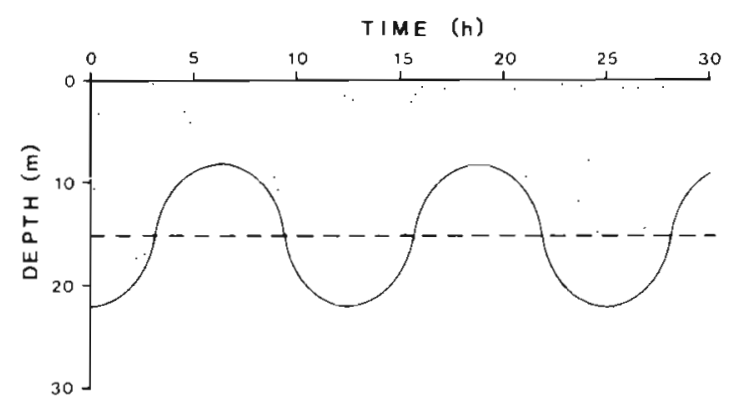

Fig. 7. Mallotus villosus. Schematic representation of the effect of internal tides on vulnerability of capelin larvae to the sampler. The sinusoidal curve represents the semidiurnal vertical motion of the picnocline which constitutes the lower boundary of the vertical distribution of the larvae (stippled area). The horizontal dashed line at depth of $15 \mathrm{~m}$ represents the lower limit of the sampler's multiple-oblique trajectory (see text)

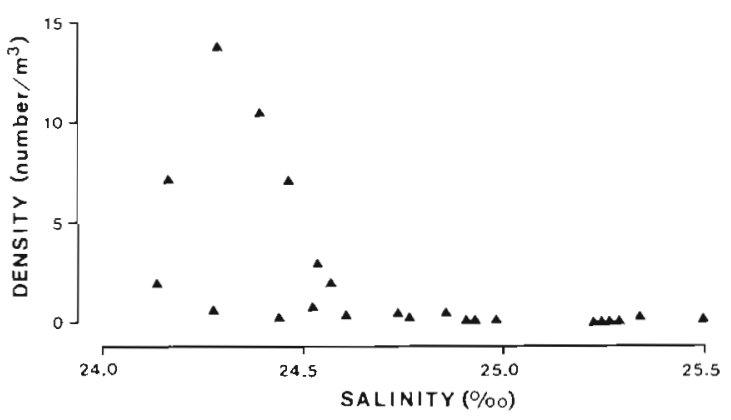

Fig. 8. Mallotus villosus. Larval capelin density in the 15 to 50 $\mathrm{m}$ (or bottom) depth interval plotted against salinity at $8 \mathrm{~m}$ during the sampling of Water Mass III

Leggett 1982, 1983), so that the lower limit of their vertical distribution will rise towards the surface every $12.5 \mathrm{~h}$. Since the sampling interval on the vertical was constant ( 0 to $15 \mathrm{~m})$, a greater proportion of water from below the pycnocline, containing little or no larvae, was filtered by the net when sampling occurred over the crest of the internal tide. This moment also corresponded to the recording of higher salinities at $8 \mathrm{~m}$, following the shoaling of the isohalines (Fig. 7). The opposite situation occurred during the trough of the internal tide when all the water column sampled contained larvae, and lower salinities were recorded following the deepening of the isohalines (Fig. 7). This hypothetical mechanism would explain the observed inverse semidiurnal covariations in capelin abundance and salinity. If internal tides were actually responsible for the phenomenon, we would expect the capture of significant numbers of capelin in the deep layer (15 to $50 \mathrm{~m}$ ), to generally correspond to the deepening of the pycnocline, and, hence, to the recording of low salinities in the surface layer. This prediction was supported by the results which show that significant numbers of capelin were captured in the deep layer only when low salinities were recorded at $8 \mathrm{~m}$ (Fig. 8).

The semidiurnal 'noise' superimposed on the trend in the decline of capelin number is thus explained in part by a time-dependent sampling artifact related to internal tides. The remaining curvilinear trend explained $54.8 \%$ of the variance in capelin abundance for Water Mass III (Fig. 6b). This trend is of greater interest than the semidiumal anomalies, since it represents the exponential decay in capelin number resulting from the combined effects of mortality and dilution of the population caused by mixing of the surface brackish waters with deep oceanic water. An estimate of the mortality rate of the larvae can be obtained by incorporating into Equation (1) a factor $V_{t}$, representing the increased volume of Water Mass III at time $t$

$$
N_{t}=\frac{N_{0} e^{-Z t}}{V_{t}}
$$


where $V_{t}=$ volume of Water Mass III at time $t ; Z$ now = rate of decay attributable to mortality only. If we assume that the increase in the salinity of Water Mass III over the 46 h of drift was due uniquely to the upward entrainment of deep, saline water across the pycnocline, the salinity at time $t, S_{\ell}$ is given by

$$
S_{t}=\frac{S_{0} V_{0}+S_{a} V_{a}}{V_{0}+V_{a}}
$$

where $\mathrm{S}_{0}$ and $\mathrm{V}_{0}=$ salinity and volume of Water Mass III at time zero; $\mathrm{S}_{\mathrm{a}}$ and $\mathrm{V}_{\mathrm{a}}=$ salinity and volume of the deep water added to Water Mass III by entrainment from time zero to time $t$. Since $V_{1}=V_{0}+V_{a}$,

$$
S_{t}=\frac{S_{0} V_{0}+S_{a}\left(V_{t}-V_{o}\right)}{V_{t}}
$$

and

$$
V_{t}=V_{o} \frac{\left(S_{a}-S_{0}\right)}{\left(S_{a}-S_{t}\right)}
$$

Capelin abundance being expressed on a per $\mathrm{m}^{3}$ basis, we can consider having started with a $1 \mathrm{~m}^{3}$ volume at $\mathrm{t}=0$ (i.e. $\mathrm{V}_{\mathrm{o}}=1$ ), and

$$
V_{t}=\frac{\left(S_{a}-S_{0}\right)}{\left(S_{a}-S_{t}\right)}
$$

Substituting in (2), we have

$$
N_{t}=N_{o} e^{-z t} \frac{\left(S_{a}-S_{t}\right)}{\left(S_{a}-S_{0}\right)}
$$

Following instrument failure, the exact value of $S_{a}$ at the time of sampling in Water Mass III could not be measured. However, salinity below the pycnocline varies from 28 to $30 \%$ in the area in summer (El-Sabh 1979, Tang 1980). Equation (3) was used to estimate $Z$, the hourly exponential rate of mortality of capelin larvae in Water Mass III, for values of $\mathrm{S}_{\mathrm{a}}$ ranging from 28 to $30 \%$ (Table 3 ). Z was also expressed as an instantaneous daily survival rate $(1-Z)^{24}$, for easier comparison with values reported in the literature. Over this range of values of $S_{a}, Z$ varied from -0.0318 to
$-0.0352 \mathrm{~h}^{-1}$ only, indicating that the choice of $\mathrm{S}_{\mathrm{a}}$ was more or less critical for the evaluation of $\mathrm{Z}$.

Correcting for the effect of mixing had little impact on the value of the exponential rate of decay obtained by fitting Equation (1) to the raw data. For example, using the median value of $\mathrm{S}_{a}=29 \%$ to correct for mixing changed our estimate from -0.0405 to -0.0339 $\mathrm{h}^{-1}$. This difference between the corrected and uncorrected estimates of $Z$ corresponded to a $6.6 \%$ difference in the instantaneous daily survival rate (43.7 vs $37.1 \% \mathrm{~d}^{-1}$ ) (Table 3 ). The uncorrected rate of decay implied an $85.1 \%$ reduction of the initial number of larvae after $46 \mathrm{~h}$, compared to $79.5 \%$ for the corrected estimate. Thus, the dilution of the population by the upward entrainment of deep water explained $5.6 \%$ of the reduction in capelin density after $46 \mathrm{~h}$.

The monitoring of the 6 other water masses was too brief to detect long-term trends in salinity or larval capelin abundance. In these short series of measures, time variations in salinity were dominated by semidiurnal fluctuations similar to those attributed to internal tides in Water Mass III. Larval capelin abundance within these water masses was negatively correlated to salinity (Fig. 9). The inverse relation between capelin density and salinity appeared non-linear. In Water Masses I, II, and IVa, where abundance and yolk sac frequency were high, the decay in capelin number as salinity increased, was sharp (Fig. 9a, c). In Water Masses IVb, V, and VI, where abundance and yolk sac frequency were low, the decay in capelin number was slow (Fig. 9c, d). These partial representations of the decay in capelin number as mixing progressed in time (i.e. as salinity increased) corresponded to the more complete picture obtained in Water Mass III (Fig. 9b).

\section{DISCUSSION}

\section{Behaviour of the drifter}

The aim of this study was to establish the survival curve of capelin over the transition from yolk sac nutri-

Table 3. Mallotus villosus. The effect of varying $S_{a}$, the salinity of the deep layer, on the estimation of $Z$, the instantaneous exponential mortality rate of larval capelin in Water Mass III (see text)

\begin{tabular}{|cccccc|}
\hline $\mathrm{S}_{\mathrm{a}}$ & $\begin{array}{c}\text { Instantaneous mortality rate } \\
\mathrm{h}^{-1}\end{array}$ & Standard deviation & \multicolumn{2}{c|}{$\begin{array}{c}95 \% \text { confidence interval } \\
\text { Lower bound }\end{array}$} & $\begin{array}{c}\text { Upaily survival bound } \\
\%\end{array}$ \\
\hline 28.0 & -0.03184 & 0.00604 & -0.04436 & -0.01931 & 46.0 \\
28.5 & -0.03301 & 0.00607 & -0.04559 & -0.02043 & 44.7 \\
29.0 & -0.03390 & 0.00609 & -0.04653 & -0.02128 & 43.7 \\
29.5 & -0.03461 & 0.00611 & -0.04727 & -0.02194 & 42.9 \\
30.0 & -0.03517 & 0.00613 & -0.04788 & -0.02247 & 42.3 \\
No correction & -0.04050 & 0.00634 & -0.05365 & -0.02735 & \\
\hline
\end{tabular}




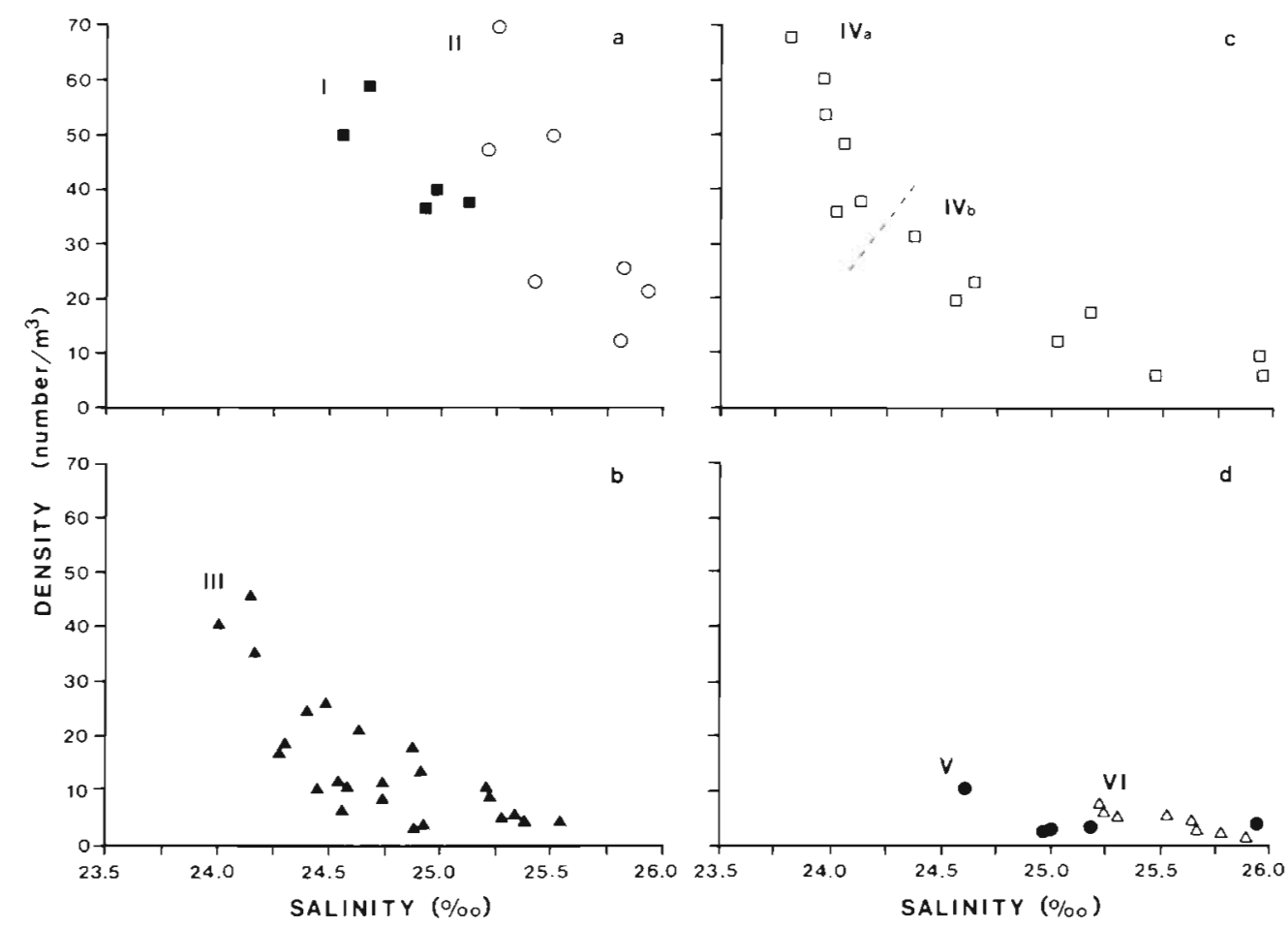

Fig. 9. Mallotus villosus. Larval capelin density as a function of salinity in the different water masses crossed by the drifter

tion to exogenous feeding, by tracking a discrete aggregation of larvae and monitoring the decline in its density. Previous reports of attempts at flagging a distinct concentration of fish larvae seldom discussed the efficiency of the drogue used (e.g. Miller et al. 1963, Dragesund \& Nakken 1971, Hempel \& Schnack 1971, Bjorke 1978, Conte et al. 1979, Henri et al. 1985). Smith et al. (1978) concluded from the small variability in the abundance and size of larval yellowtail flounder Limanda ferruginea captured over $3 \mathrm{~d}$, that their freedrifting buoy remained in the same aggregation of larvae. Shelton \& Hutchings (1982) reached the same conclusion from the lack of variability in temperature, salinity, and the specific composition of zooplankton around their parachute drogue.

In the present study, direct measurement of the movement of the drifter relative to the surrounding water revealed a net progression of $22.8 \mathrm{~km}$ away from the initial volume of water. The failure of the drogue to remain within the same volume of water likely resulted from the drag on the supporting buoy. The cross-correlation between wind stress and the speed of the drifter relative to the surrounding water supports the hypothesis that wind-induced accelerations of the top meters of the water column were transmitted to the drogue via this drag on the supporting buoy. A more sophisticated design (e.g. neutral buoyancy drogue with underwater localization system) could certainly allow for a more accurate tracking of a given volume of water.
While wandering away from the initial volume of water, the drifter apparently intersected several distinct elements of a large-scale mosaic of water masses forming the surface layer in the area. Over the $5.6 \mathrm{~d}$ of the experiment, this mosaic drifted for $150 \mathrm{~km}$, following the general surface circulation in the lower estuary. The shape of the water masses remains unknown, but they could correspond to the meso-scale eddies (1 to $10 \mathrm{~km}$ ) visible on satellite thermo-imagery of the area (e.g. Lavoie et al. 1984). A very rough estimate of the average horizontal dimension of the hydrodynamic structures involved is obtained by dividing the net displacement measured $(22.8 \mathrm{~km})$ by the number of water masses crossed (7). The resulting value of $\sim 3 \mathrm{~km}$ is consistent with the observation, in the area, of near-surface (depth $=3 \mathrm{~m}$ ) salinity 'patches' with a modal dimension of $2 \mathrm{~km}$ (Levasseur et al. 1983).

\section{Capelin mortality}

In 1 instance, the drogue remained in the same water mass for $46 \mathrm{~h}$ (Water Mass III). Over this period, capelin concentration around the drifter decreased by $85.1 \%$. Dilution of the population by the upward entrainment of deep water contributed for only $5.6 \%$ of the reduction in capelin density. A corrected estimate of the mortality rate was obtained by taking into account the effect of mixing into the model used to describe the decay in capelin density. The correction was based on 
the assumption that the increase in the salinity of Water Mass III resulted uniquely from the upward entrainment of saline water across the pycnocline. In a partially mixed estuary such as the lower St. Lawrence in summer (El-Sabh 1979), the increase in the salinity of the surface layer results primarily from vertical exchanges with the deep saline layer (Pritchard 1955). However, mixing across the pycnocline is a 2-way process implying both the upward entrainment of deep water and the downward entrainment of brackish water (Dyer 1973, p. 9). Thus a significant volume of water is entrained downward, compensating for the upward entrainment of saline water. It follows that our estimate of the increase in the volume of Water Mass III, resulting from a given increase in salinity, is a maximum estimate. Consequently, the fraction of the decline in larval capelin density attributed to mixing is probably overestimated, and the mortality rate calculated by subtracting this fraction from the observed decline in number is likely to slightly underestimate the true mortality.

In marine fish, estimates of daily survival rate of yolk sac larvae range in general from 75 to $95 \% \mathrm{~d}^{-1}$ (see Dahlberg 1979 for a review). Dekhnik (1963, 1964, cited by Dahlberg 1979) reports relatively low survivals of 52.7 and $61.8 \% \mathrm{~d}^{-1}$ respectively for Black Sea anchovy Engraulis encrasicholus and Black Sea mackerel Trachurus mediterraneus yolk sac larvae. Farris (1961) gives a value of $60.0 \% \mathrm{~d}^{-1}$ survival for yolk-sac jack mackerel Trachurus symmetricus. At $43.7 \% \mathrm{~d}^{-1}$. the daily survival rate of capelin measured during the final resorption of the vitelline reserves is substantially lower than these values. There are several possible interpretations for this low value. First, it is possible that environmental conditions were exceptionally unfavorable in Water Mass III and that survival therein was atypical of the average survival of capelin larvae. Partial results from the other water masses suggest however that the rate of decay in capelin abundance measured in Water Mass III prevailed in the whole area (Fig. 9).

Second, intense horizontal mixing of Water Mass III with adjacent water masses containing little or no larvae could have contributed significantly to the decrease in larval capelin concentration attributed to mortality. However, intense horizontal mixing would also have resulted in the homogenization of the T-S characteristics of adjacent water masses. Over the time scales investigated in this study, there was little evidence for such an homogenization, as shown by the limited number of T-S points falling outside the distinct $\mathrm{T}$-S signatures of the different water masses (Fig. 2). This last observation suggests that density gradients at the boundaries between the water masses substantially reduced turbulent exchanges. Assuming that the larvae are dispersed in the horizontal plane by the same turbulent processes that disperse the freshwater fraction of the upper layer, we would conclude that horizontal diffusion contributed to homogenize the concentration of the larvae within a given water mass but was too weak to cause exchange of larvae across the density barriers separating the water masses. In previous studies, we verified the above assumption and found that active behaviours such as swimming or vertical migrations played little if any role in increasing the horizontal diffusivity of larval and early postlarval stages of capelin (Fortier \& Leggett 1982, 1983).

A third interpretation for the low survivorship measured at the very end of the yolk sac stage in capelin, is that survival at that point in development was unrepresentative of the survival rate prevailing over the yolk sac stage, but rather reflected a period of increased mortality. This last interpretation would lend support to the hypothesis postulating the existence of a critical period of higher mortality at the transition from endogenous to exogenous feeding (Hjort 1914, 1926).

\section{Hjort's hypothesis}

As restated by May (1974), Hjort's hypothesis (1914, 1926) proposes 'that the strength of a year-class is determined by the availability of planktonic food shortly after the larval yolk supply has been exhausted'. While starvation is assumed to be the fundamental cause of mortality, increased susceptibility of the starving larvae to predation could be the immediate agency of their disappearance (Wyatt 1972, Jones 1973, May 1974, Hunter 1976, Fortier \& Leggett 1984). The survival curve predicted by Hjort's hypothesis can be described by the logistic equation

$$
N_{t}=\frac{K}{1+e^{a-Z_{m}}}
$$

where $\mathrm{K}=$ initial concentration of larvae at emergence; $\mathrm{a}=$ an integration constant to position the curve relative to the origin. In Equation (4), $\mathrm{Z}_{\mathrm{m}}$ does not represent the actual or realized mortality rate as $Z$ in Equation (3), but rather the maximum potential mortality rate of larval capelin. In the logistic model, the realized mortality rate will vary along the sigmoid survival curve, being minimum at the beginning of the curve, maximum at its inflection and minimum again at its end. This sequence corresponds to the survival curve predicted by Hjort's hypothesis, in which mortality should be minimum at the onset of yolk sac life, maximum at the resorption of the vitelline reserves, and low again among those larvae that survived the transition to exogenous feeding. 
Correcting for mixing as in (3), we have

$$
N_{t}=\frac{K}{1+e^{a-Z_{m} !}} \frac{\left(S_{a}-S_{t}\right)}{\left(S_{a}-S_{o}\right)}
$$

$\mathrm{K}$, the initial concentration of larvae, ranged from 50 to 450 larvae $\mathrm{m}^{-3}$ at peak emergence in the St. Lawrence upper estuary (Fortier \& Leggett unpubl.). Equation (5) was adjusted to abundance data from Water Mass III, using a typical value of $K=300$ larvae $\mathrm{m}^{-3}$. The fit of the logistic model to the observations compared with that of the exponential model $\left(\mathrm{r}^{2}=0.567\right.$ vs $\mathrm{r}^{2}=$ 0.566). The estimate of $Z_{m}$ the maximum potential mortality rate, was $-0.0361 \mathrm{~h}^{-1}$, a value slightly superior to the estimate of $Z$, the realized mortality rate from the exponential model $\left(-0.0339 \mathrm{~h}^{-1}\right)$.

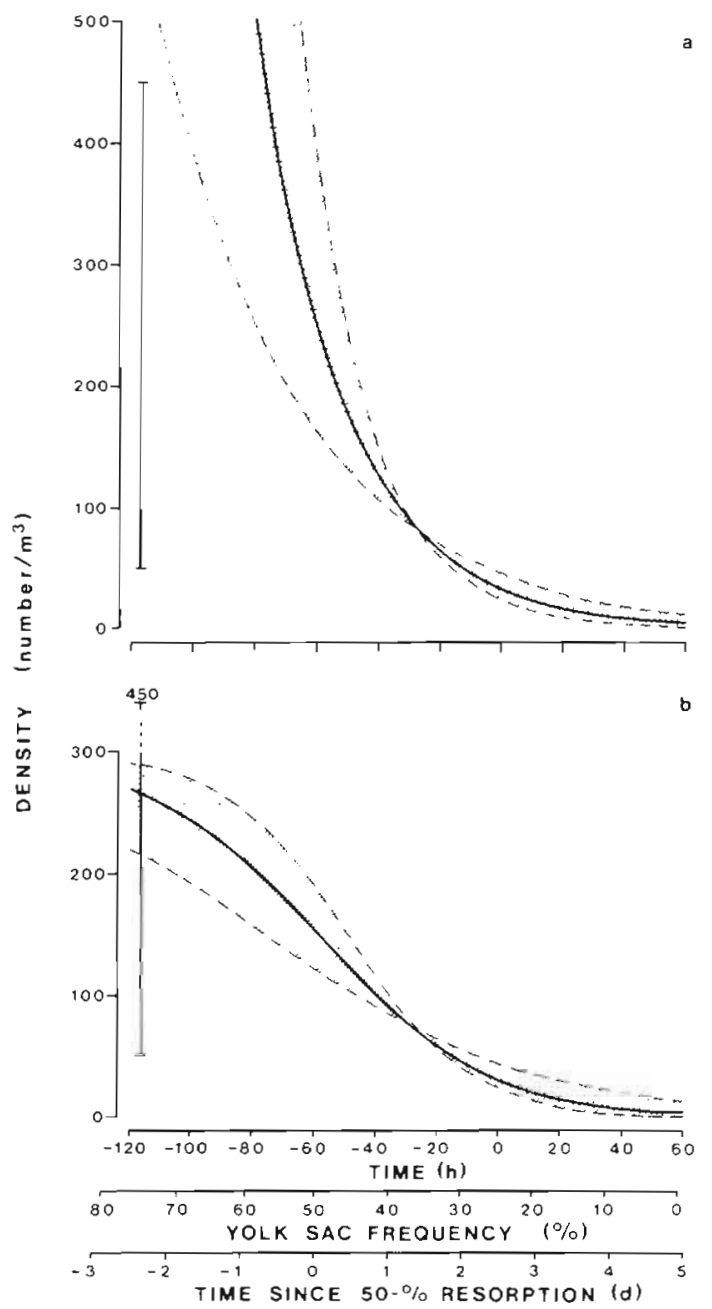

Fig. 10. Mallotus villosus. Reconstruction of larval capelin mortality curve (solid line) from emergence to final yolk resorption, based on the models of exponential decay (a) and logistic decay (b) fitted to abundance data from Water Mass III. Shadings represent the $95 \%$ confidence area for predicted abundance. The vertical range bar at time $-120 \mathrm{~h}$ illustrates the range in capelin abundance during peak emergence in the St. Lawrence upper estuary (Fortier \& Leggett unpubl.)
Both models were used to extrapolate the survival curve of capelin from emergence to final yolk-sac exhaustion (Fig. 10). In Fig. 10, the time axis was doubled with a yolk sac frequency axis by assuming that the linear relation between yolk sac frequency and time in Water Mass III (Fig. 5) held over the entire period. The emergence of the larvae was considered to have occurred at a yolk sac frequency of $75.8 \%(\mathrm{t}=$ -120 h, Fig. 10), that is, the average yolk sac frequency in capelin populations emerging from the spawning grounds of the upper estuary (SD $=18.2 \%$, $\mathrm{n}=66$; Fortier \& Leggett unpubl.).

The exponential model predicted values of capelin abundance at emergence that exceeded the range of abundance observed during peak emergence (Fig. 10a). It is thus unlikely that the high exponential mortality rate measured at the exhaustion of the vitelline reserves in Water Mass III prevailed during the entire yolk sac life of the cohort. Owing to the additional parameter $\mathrm{K}$, the logistic model reflecting Hjort's hypothesis predicted values of abundance at emergence that fell within the range of the observations (Fig. 10b). The realized rate of mortality along the survival curve produced by the logistic model was maximum near $\mathrm{t}=-60 \mathrm{~h}$, when yolk sac frequency was $50 \%$ (Fig. 10b). This is in agreement with Hjort's hypothesis predicting a maximum mortality at the exhaustion of the vitelline reserves, that is by definition, when $50 \%$ of the larvae have resorbed their yolk.

In summary, both models explained adequately the decay in capelin abundance monitored in Water Mass III, but the backward extrapolation of the survival curve indicated that only the logistic model reflecting Hjort's hypothesis yielded realistic values of capelin density at emergence. Based on the observation of larval capelin decline in Water Mass III, we cannot reject Hjort's contention that mortality increases at the final resorption of the yolk reserves. However, our conclusions are based on a single estimate of the mortality rate of capelin during the final days of yolk sac life. Firmer conclusions as to the exact shape of capelin early survival curve will be reached when the entire period of passive drift can be monitored.

\section{Spatial variability in survival}

According to the present paradigm, the severity of mortality at the end of the yolk sac stage will depend both on the availability of suitable prey for the larvae and on predation. These conditions are likely to vary within the geographical distribution of the larval and postlarval stages of a given stock. In the St. Lawrence lower estuary, capelin larvae were concentrated within the surface layer $(<15 \mathrm{~m})$, indicating that the vertical 

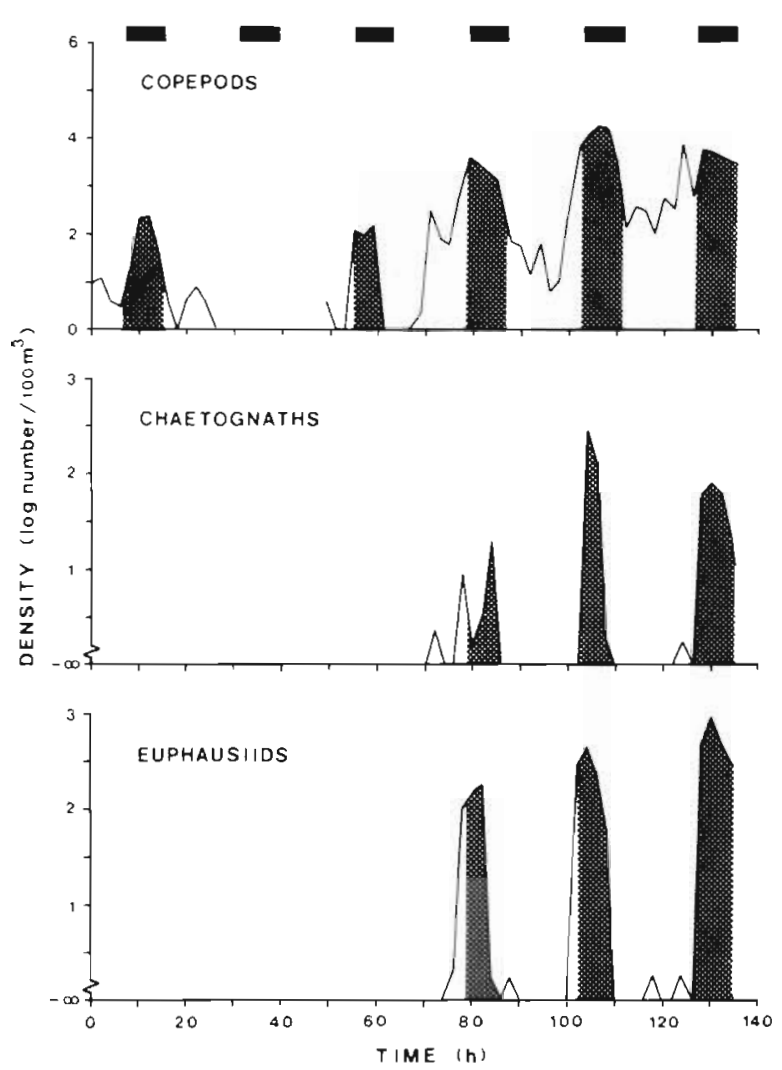

Fig. 11. Time series of macrozooplankton abundance in the surface layer $(0$ to $15 \mathrm{~m})$ of the St. Lawrence lower estuary. Shaded areas correspond to night

transfer of larvae to the deep layer was limited. As pointed out earlier, horizontal turbulent exchange of larvae between the distinct water masses forming the surface layer also seemed limited. Hence, each water mass appeared to form a discrete ecological unit in which a subpopulation of capelin larvae was trapped. Potential predators occupied these units at night only, when invading the surface layer from the deep layer (Fig. 11). The triggering of capelin emergence by onshore winds in coastal Newfoundland also resulted in the association of capelin larvae with surface water masses characterized by relatively good feeding conditions and reduced predator abundance (Frank \& Leggett 1982). Variations in the abundance, the pattern of aggregation and/or the nutritional value of the microzooplankton developing in the different water masses could generate significant spatial heterogeneity in larval fish survival.

A dispersing population is often best considered as a set of local subpopulations each subject to different environmental conditions (Andrewartha \& Birch 1954). This seems to apply for capelin larvae in the St. Lawrence estuary, where survival of a given subpopulation over the transition from yolk sac to exogenous feeding will depend on the environmental conditions develop- ing in the discrete water mass transporting this subpopulation. For management purposes, the fate of the population as a whole is of interest, recruitment being the integration of the survival of all the subpopulations (den Boer 1968). Yet, to understand how temporal and spatial variability of the environment affects population numbers, we must look at units smaller than the population (Roff 1974). With an improvement of the methodological aspects, the approach used in the present study could certainly provide a more complete picture of the early survival curve of the planktonic stages of fish. However, a more direct approach such as the small-scale (10 to $100 \mathrm{~m}$ ) sampling of the horizontal distribution of the early postlarvae, their food, and their predators, would likely yield more information on the relative survival in different subpopulations. In the dispersal area of capelin, most of the spatial variability in the survival of early postlarvae should occur at scales corresponding to the horizontal dimensions of the ecological units formed by the distinct surface water masses ( 1 to $10 \mathrm{~km}$ ). We would then predict that a potential dependance of early postlarval survival and/or growth on food availability or any other environmental factor will be detected at these mesoscales.

Acknowledgements: Logistic and financial support was provided by GIROQ (Groupe interuniversitaire de recherches océanographiques du Québec), le Ministère de l'Education du Québec (FCAC), the Natural and Engineering Research Council of Canada, and the Department of Supply and Services of Canada. Jacques Bertrand, Robert Bélanger, Norma Chalouhi, Denis Croteau, Dominique Fortier, Pierre Lambert, Patrick Ouellet, Kathleen Tallon, and Shannon van Wagner provided assistance at sea and in the laboratory. Kathleen Tallon measured the larvae. Esther Bonneau and DominiqueMousseau Tremblay assisted with the preparation of the illustrations. The authors also acknowledge the significant contribution of an anonymous referee to the interpretation of the results.

\section{LITERATURE CITED}

Andrewartha, H. G., Birch, L. C. (1954). The distribution and abundance of animals. Chicago Univ. Press, Chicago

Beyer, J. E., Laurence, G. C. (1979). A stochastic model of larval fish growth. Ecol. Modeling 8: 109-132

Bjorke, H. (1978). Food and feeding of young herring larvae of Norwegian spring spawners. FiskDir. Skr. Ser. Havunders. 16: 405-421

Conte, M. H., Otto, R. G., Miller, P. E. (1979). Short-term variability in surface catches of ichthyoplankton in the Upper Chesapeake Bay. Estuar. coast. mar. Sci. 8: 511-522

Cushing, D. H. (1972). The production cycle and the number of marine fish. Symp. zool. Soc. Lond. 29: 213-232

Dahlberg, M. D. (1979). A review of survival rates of fish and larvae in relation to impact assessments. Mar. Fish. Rev. 41: $1-12$

de Lafontaine, Y., Sinclair, M., El-Sabh, M. I., Lassus, C., 
Fournier, R. (1984). Temporal occurrence of ichthyoplankton in relation to hydrographic and biological variables at a fixed station in the St. Lawrence estuary. Estuar. coast. Shelf Sci. 18: 177-190

de Lafontaine, Y., Sinclair, M., Messieh, S. N., El-Sabh, M. I., Lassus, C. (1981). Ichthyoplankton distributions in the northwestern Gulf of St. Lawrence. Rapp. P.-v. Réun Cons. int. Explor. Mer 178: 185-187

Dekhnik, T, V (1963). Patterns of variation in abundance and mortality of Engraulis encrasicholus ponticus Alex eggs and larvae in the Black Sea. Tr. Sevastop. Biol. Stn. Im. A. D. Kovalenskogo Akad. Nauk. Ukr. SSR 15: 292-301

Dekhnik, T. V. (1964). Changes in the abundance of Black Sea mackerel eggs and larvae during the development period. Tr. Sevastop. Biol. Stn. Im. A. D. Kovalenskogo Akad. Nauk. Ukr. SSR 16: 340-358

den Boer, P. J. (1968). Spreading of risk and stabilization of animal numbers. Acta Biotheor. 18: 165-194

Dragesund, O., Nakken, O. (1971). Mortality of herring during the early larval stage in 1967 . Rapp. P.-v. Réun. Cons. int. Explor. Mer 160: 142-146

Dyer, K. R. (1973). Estuaries: a physical introduction. John Wiley and Sons, London

El-Sabh, M. I. (1979). The lower St. Lawrence estuary as a physical oceanographic system. Nat. Can. 106: 55-73

El-Sabh, M. I., Lie, H.-J., Koutitonsky, V. G. (1982). Variability of the near-surface residual current in the lower St. Lawrence estuary. J. geophys. Res. 87: 9589-9600

Farris, D. A. (1961). Abundance and distribution of eggs and larvae and survival of larvae of jack mackerel (Trachurus symmetricus). Fish. Bull. U.S. 61: 247-279

Forrester, W. D. (1974). Internal tides in the St. Lawrence estuary. J. mar. Res. 32: 55-66

Fortier, L., Leggett, W. C. (1982). Fickian transport and the dispersal of fish larvae in estuaries. Can. J. Fish. aquat. Sci. 39: 1150-1163

Fortier, L., Leggett, W. C. (1983). Vertical migrations and transport of larval fish in a partially mixed estuary. Can. J. Fish. Aquat. Sci. 40: 1543-1555

Fortier, L., Leggett, W. C. (1984). Small-scale covariability in the abundance of fish larvae and their prey. Can. J. Fish. Aquat. Sci. 41: 502-512

Frank, K. T., Leggett, W. C. (1981). Wind regulation of emergence times and early larval survival in capelin (Mallotus villosus). Can. J. Fish. Aquat. Sci. 38: 215-223

Frank, K. T., Leggett, W. C. (1982). Coastal water mass replacement: its effect on zooplankton dynamics and the predator-prey complex associated with larval capelin (Mallotus villosus). Can. J. Fish. Aquat. Sci. 39: 991-1003

Gullard, J. A. (1965). Survival of the youngest stages of fish, and its relation to year-class strength. Int. Comm. Northwest Atl. Fish (ICNAF) Spec. Publ. 6: 363-371

Hempel, G., Schnack, D. (1971). Larval abundance on spawning grounds of Banks and Downs herring. Rapp. P.-v. Réun. Cons. int. Explor. Mer 160: 94-98

Henri, M., Dodson, J. J., Powles, H. (1985). Spatial configurations of young herring (Clupea harengus harengus) larvae in the St. Lawrence estuary: importance of biological and physical factors. Can. J. Fish. Aquat. Sci. 42 (Suppl. 1): 91-104

Hjort, J. (1914). Fluctuations in the great fisheries of northern Europe viewed in the light of biological research. Rapp. P.-v. Réun. Cons. Perm. int. Explor. Mer 20: 1-228

Hjort, J. (1926). Fluctuations in the year classes of important food fishes. J. Cons. Perm. int. Explor Mer 1: 5-38

Hunter, J. R. (1976). Report on a colloquium on larval fish mortality studies and their relation to fishery research,
January 1975. US Dept. Commer. Nat. Oceanic Atmos. Adm. (NOAA) Tech. Rep. NMFS CIRC-395: p. 1-5

Jacquaz, B., Able, K. W., Leggett, W. C. (1977). Seasonal distribution, abundance, and growth of larval capelin (Mallotus villosus) in the St. Lawrence estuary and northwestern Gulf of St. Lawrence. J. Fish. Res. Bd Can. 34: 2015-2029

Jones, R. (1973). Density dependent regulation of the number of cod and haddock. Rapp. P.-v. Réun. Cons. int. Explor. Mer 164: 156-173

Lasker, R. (1975). Field criteria for survival of anchovy larvae: the relation between inshore chlorophyll maximum layers and successful first feeding. Fish. Bull. U.S. 73: 453-462

Lasker, R. (1981). Factors contributing to variable recruitment of the northern anchovy (Engraulis mordax) in the California current: contrasting years, 1975 through 1978. Rapp. P.-v. Réun. Cons. int. Explor. Mer 178: 375-388

Lavoie, A., Bonn, F., Dubois, J. M., El-Sabh, M. I. (1984). Etude thermique des eaux de l'estuaire du Saint-Laurent à l'aide du satellite HCMM: résultats préliminaires. In: Assoc. Québécoise de Télédétection (ed.) Proc. of the 8th Can. Symp. on Remote Sensing, Montreal, p. 321-330

Leiby, M. M. (1984). Life history and ecology of pelagic fish eggs and larvae. In: Steidinger, K. A., Walker, L. M. (ed.) Marine plankton life cycle strategies. CRC Press, Boca Raton, Florida, p. 121-140

Levasseur, M., Therriault, J. C., Legendre, L. (1983). Tidal currents, winds, and the morphology of phytoplankton spatial structures. J. mar. Res. 41: 655-672

Marr, J. C. (1956). The 'critical period' in the early life history of marine fishes. J. Cons. int. Explor. Mer 21: 160-170

May, R. C. (1974). Larval mortality in marine fishes and the critical period concept. In: Blaxter, J. H. S. (ed.) The early life history of fish. Springer-Verlag, New York, p. 3-19

Miller, D., Colton, J. B. Jr., Marak, R. P. (1963). A study of the vertical distribution of larval haddock. J. Cons. int. Explor. Mer 28: $37-49$

Parent, S., Brunel, P. (1976). Aires et périodes de fraie du Capelan (Mallotus villosus) dans l'estuaire et le golfe Saint-Laurent. Trav. Pech. Que. 45: 1-46

Pritchard, D. W. (1955). Estuarine circulation patterns. Proc. Am. Soc. civ. Engrs 81: 1-11

Roff, D. A. (1974). The analysis of a population model demonstrating the importance of dispersal in a heterogeneous environment. Oecologia (Berl.) 15: 259-275

Russell, F. S. (1976). The eggs and planktonic stages of British marine fishes. Academic Press, London

Saville, A., Schnack, D. (1981). Some thoughts on the current status of studies of fish egg and larval distribution and abundance. Rapp. P.-v. Réun. Cons. int. Explor. Mer 178: $153-157$

Shelton, P. A., Hutchings, L. (1982). Transport of anchovy, Engraulis capensis Gilchrist, eggs and early larvae by a frontal jet current. J. Cons. int. Explor. Mer 40: 185-198

Shepherd, J. G., Cushing, D. H. (1980). A mechanism for density-dependent survival of larval fish as the basis of a stock-recruitment relationship. J. Cons. int. Explor. Mer 39: $160-167$

Smith, P. E. (1978). Biological effects of ocean variability: time and space scales of biological response. Rapp. P.-v. Réun. Cons. int. Explor. Mer 173: 117-127

Smith, W. G., Sibunka, J. D., Wells, A. (1978). Diel movements of larval yellowtail flounder, Limanda ferruginea, determined from discrete depth sampling. Fish. Bull. U.S. 76: $167-178$

Solemdal, P., Ellersten, B. (1984). Sampling fish larvae with large pumps; quantitative and qualitative comparisons 
with traditional gear. In: Dahl, E., Danielssen, D. S., Moksness, E., Solemdal, P. (ed.). The propagation of cod Gadus morhua L. Flødevigen rapportser 1: 335-363

Talbot, J. W. (1977). The dispersal of plaice eggs and larvae in the Southern Bight of the North Sea. J. Cons. int. Explor. Mer 37: 221-248

Talbot, J. W. (1978). Changes in plaice larval dispersal in the last fifteen years. Rapp. P.-v. Réun. Cons. int. Explor. Mer 172: $114-123$
Tang, C. L. (1980). Mixing and circulation in the Northwestern Gulf of St. Lawrence: a study of a buoyancy-driven current system. J. geophys. Res. 85: 2787-2796

Vlymen, W. J. (1977). A mathematical model of the relationship between larval anchovy (Engraulis mordax) growth prey microdistribution, and larval behavior. Environ. Biol. Fish. 2: 211-233

Wyatt, T. (1972). Some effects of food density on the growth and behaviour of plaice larvae. Mar. Biol. 14: 210-216

This paper was presented by Dr. R. Lasker; it was accepted for printing on June 24, 1985 